\title{
CHRONOLOGICAL AND DIETARY ASPECTS OF THE HUMAN BURIALS FROM AJDOVSKA CAVE, SLOVENIA
}

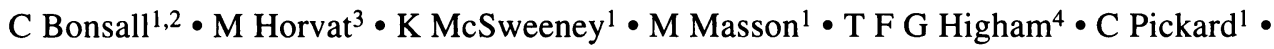 \\ G T Cook ${ }^{5}$
}

\begin{abstract}
Ajdovska Jama (The Pagan's Cave) in southeast Slovenia lies within the catchment of the River Sava, a major tributary of the Danube. The site is well known for its Neolithic burials and has been excavated to a high standard on various occasions since 1884. The human remains at the site occurred as distinct clusters of mainly disarticulated bones belonging to at least 31 individuals. Hitherto, dating of the burials has been based on the associated archaeological finds, including a few low-precision radiometric radiocarbon measurements on charred plant material. In the present study, bones from 15 individuals were subsampled for accelerator mass spectrometry (AMS) and stable isotope analyses. These comprised adults and children from 3 of the clusters. The results of the study indicate that the burials all belong to a relatively short time interval, while the stable isotope data indicate a mixed diet based on $\mathrm{C}_{3}$ plant and animal food sources. These interpretations differ somewhat from those of previous researchers. The AMS ${ }^{14} \mathrm{C}$ and stable isotope analyses form part of a wider investigation of dietary and demographic change from the Mesolithic to the Iron Age in the Danube Basin.
\end{abstract}

\section{INTRODUCTION}

This paper forms part of a wider study of prehistoric human populations in the Danube Basin, which focuses particularly on mortality profiles, variations in health and diet, and the incidence of violent trauma. Our sample populations are drawn from different archaeological periods and environments spanning the period from Mesolithic to Iron Age ( 10,000-2000 BP) (Figure 1).

Our initial research concentrated on the Iron Gates section of the Danube Valley along the Romania/ Serbia border (Bonsall et al. 1997, 2000, 2004). The Iron Gates has the largest concentration of Mesolithic open-air settlements in southeast Europe. More than 30 sites have been investigated along this $230-\mathrm{km}$ stretch of the Danube and human remains have been recovered from 11 of these, with 4 sites-Lepenski Vir, Padina, and Vlasac in Serbia; and Schela Cladovei in Romania - each producing more than a hundred burials. Many of these sites were also occupied during later periods. Radiocarbon dating demonstrates that the burials in the Iron Gates sites range in age from early Mesolithic ( 10,000 BP) to post-Medieval ( 400 BP) (Bonsall et al. 2004).

Our research in the Iron Gates, involving paired accelerator mass spectrometry (AMS) ${ }^{14} \mathrm{C}$ and stable ( $\mathrm{C}$ and $\mathrm{N}$ ) isotope measurements on human bone collagen, has indicated a heavy dietary emphasis on freshwater resources throughout the Mesolithic (Bonsall et al. 1997, 2000, 2004). It also demonstrated a ${ }^{14} \mathrm{C}$ reservoir effect, of a similar magnitude to the marine reservoir effect, due to consumption of these resources. This significantly influences the dating of human remains, which are important for developing archaeological chronologies in the Iron Gates region. However, it was possible to correct for this effect using the $\delta^{15} \mathrm{~N}$ value of the human bone collagen as an indicator of the extent of freshwater resource consumption and the offset between paired ungulate and human bones as an indicator of the magnitude of the effect (Cook et al. 2001, 2002).

\footnotetext{
${ }^{1}$ Archaeology, University of Edinburgh, Infirmary Street, Edinburgh EH1 1LT, United Kingdom.

${ }^{2}$ Corresponding author. Email: C.Bonsall@ed.ac.uk.

${ }^{3}$ Archaeology, University of Ljubljana, Slovenia.

${ }^{4}$ Oxford Radiocarbon Accelerator Unit, Research Laboratory for Archaeology and the History of Art, Oxford University, Dyson Perrins Building, Oxford OX1 3QY, United Kingdom.

${ }^{5}$ SUERC, Scottish Enterprise Technology Park, East Kilbride G75 0QF, United Kingdom.
} 


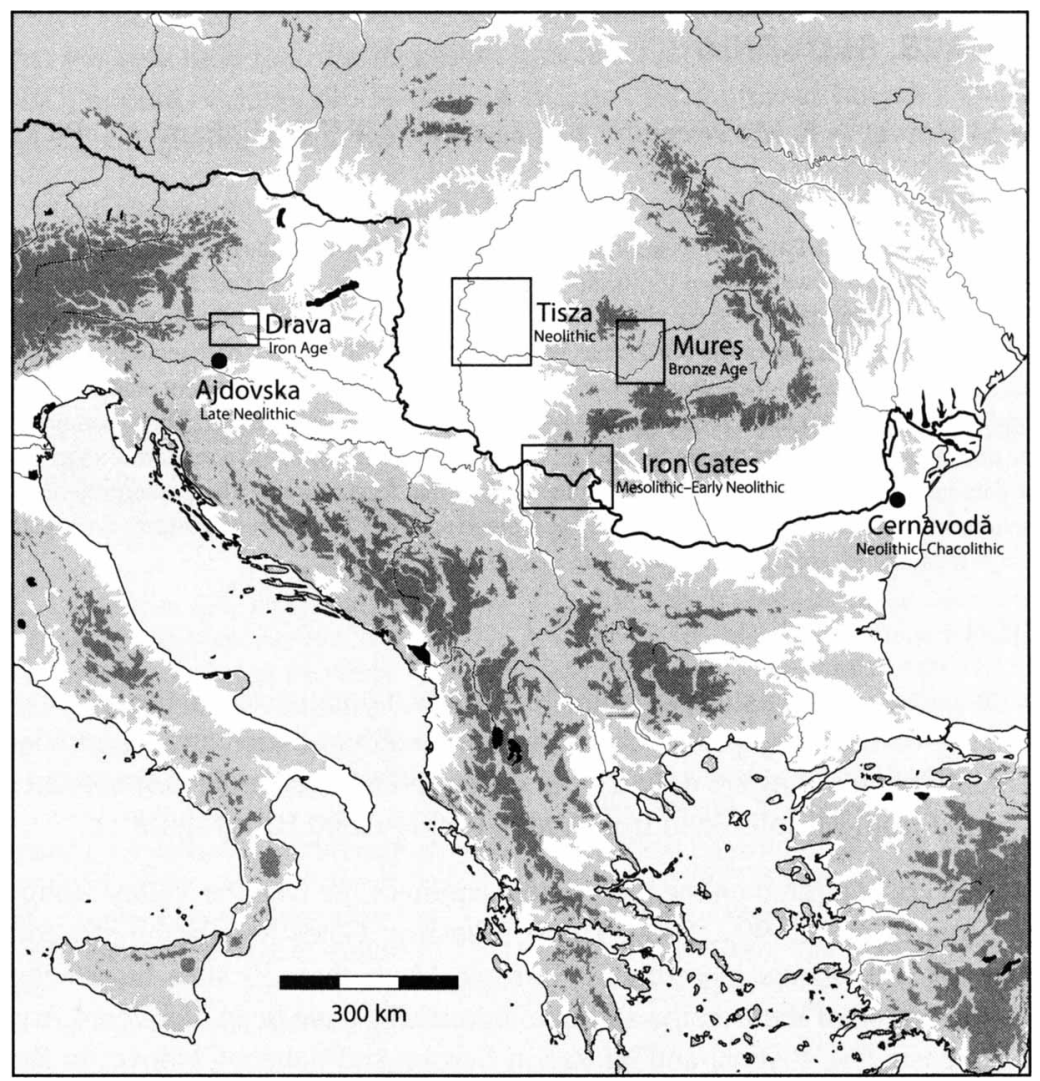

Figure 1 Map of the Danube Basin showing the locations of Ajdovska Cave and other sample populations included in the wider research program.

There is a marked change in the stable isotope values around $6000 \mathrm{cal} \mathrm{BC}$. The median $\delta^{15} \mathrm{~N}$ for 12 burials from Lepenski Vir dated between $\sim 6300-6000 \mathrm{cal}$ BC is $+15.7 \%$, while the median value for 5 burials dated between 6000 and $5600 \mathrm{cal} \mathrm{BC}$ is $+10.8 \%$ o. This suggests a substantial increase in the consumption of terrestrial foods, which has been interpreted as reflecting the transition to farming in this region (Bonsall et al. 1997, 2000). If so, the transition occurred no later in the Iron Gates than elsewhere in neighboring areas of the northern Balkans. This evidence contradicts previous ideas of a lengthy "survival" of the Mesolithic hunter-gatherer way of life in the Iron Gates. Nevertheless, the first farmers within the Iron Gates continued to use freshwater resources, as evidenced by i) $\delta^{15} \mathrm{~N}$ values for human bone collagen that are still enriched relative to those typical of a totally terrestrialbased diet, and ii) the occurrence of large numbers of fish bones in the archaeological record of this period in the Iron Gates (Bartosiewicz et al. 2001).

The continued use of aquatic resources in the earliest Neolithic is not confined to the Iron Gates. Stable isotope data suggest significant use of freshwater resources at some Early Neolithic (Körös culture) sites on the Hungarian Plain (Figure 2). This is perhaps not surprising given that the rivers in this region are some of the largest in Europe and between 6000-5500 cal BC the Danube Basin was effectively the agricultural "frontier." 


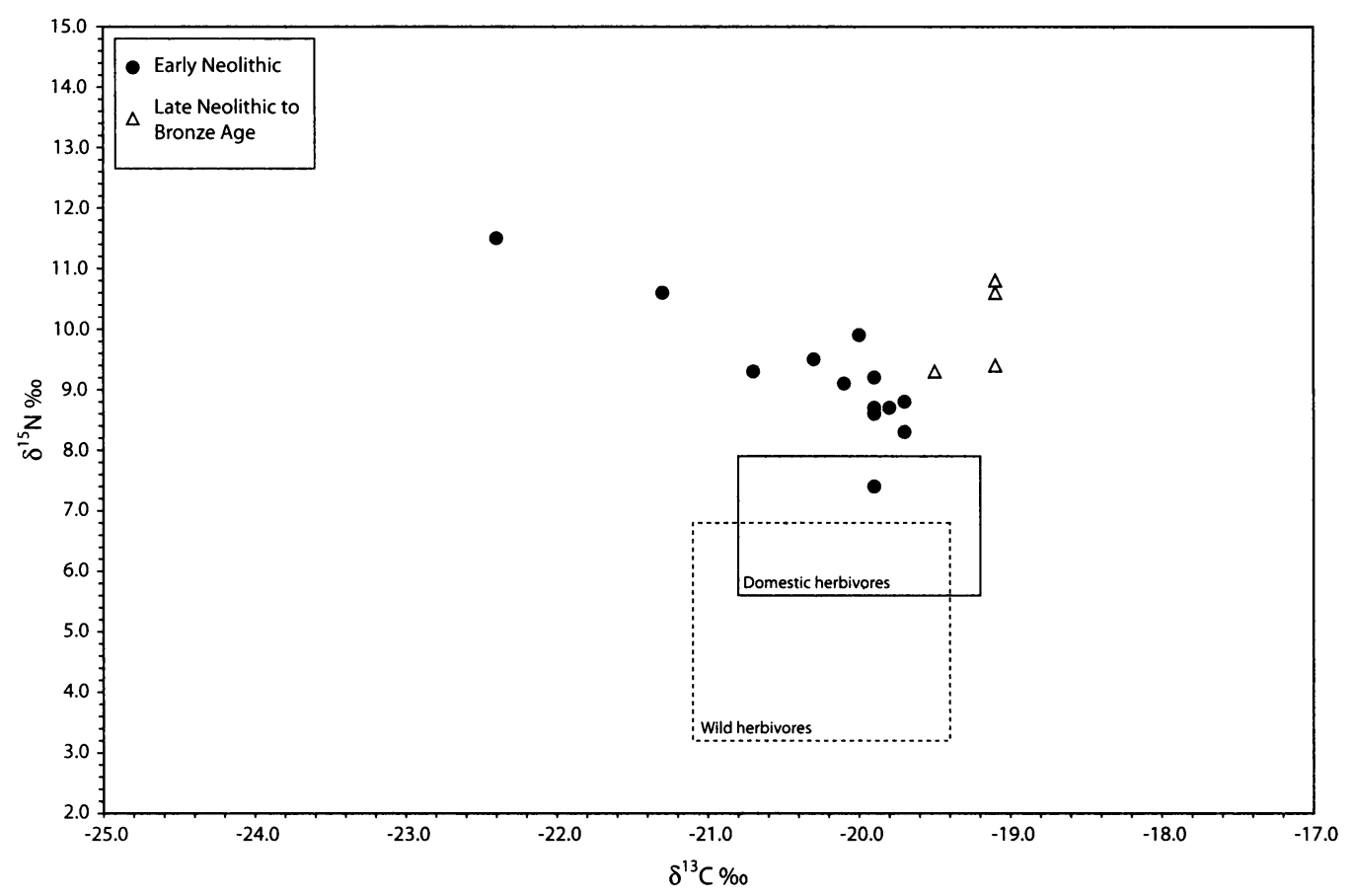

Figure 2 Carbon and nitrogen isotope ratios for human bone collagen from Early Neolithic sites on the Hungarian Plain plotted against the typical ranges for domestic and wild herbivores (data from Whittle et al. 2002). In this environment, a $\delta^{13} \mathrm{C}$ value lighter than approximately $-21 \%$ o combined with a $\delta^{15} \mathrm{~N}$ value heavier than approximately $+10 \%$ o suggests a diet that included significant amounts of protein from freshwater fish. Whittle et al. (2002) interpreted the skeleton with the lightest $\delta^{13} \mathrm{C}$ value as "Mesolithic"; however, the contracted body position is characteristic of the Early Neolithic, and the ${ }^{14} \mathrm{C}$ age of $7765 \pm 55 \mathrm{BP}$ may include a significant reservoir effect owing to consumption of river fish (Bonsall et al. 2004).

Some later burials at Lepenski Vir that have $\delta^{15} \mathrm{~N}$ values within the Early Neolithic range exhibit significantly heavier $\delta^{13} \mathrm{C}$ values. These are thought to be due to the inclusion of millet (Panicum miliaceum or Setaria italica), an introduced $\mathrm{C}_{4}$ crop plant, in the diet either directly or indirectly through its use as fodder for livestock (Bonsall et al. 2000). Judging from the ${ }^{14} \mathrm{C}$ evidence this change occurred in the Iron Gates sometime between the Chalcolithic ( 4000 cal BC) and the Roman period ( AD 300), possibly in the latter part of this time range. Elsewhere in the Danube Basin, elevated $\delta^{13} \mathrm{C}$ values consistent with direct or indirect consumption of millet are clearly evident in skeletons belonging to the pre-Roman Iron Age (Murray and Schoeninger 1988; Whittle et al. 2002). Tracing the rise of millet cultivation in the Danube Basin is one of our research priorities. Broomcorn millet (Panicum miliaceum) occurs sporadically in the archaeobotanical record of southeast Europe as early as 5500-6000 cal BC (Zohary and Hopf 1994). Throughout the region as a whole, it appears to have been a minor crop for several millennia after its introduction, though locally it may have been important. Conceivably, millet consumption accounts for the slightly heavier $\delta^{13} \mathrm{C}$ values exhibited by Late Neolithic/Bronze Age skeletons from the Hungarian Plain compared to earlier Neolithic populations (Figure 2), although more data are needed to test this hypothesis. 


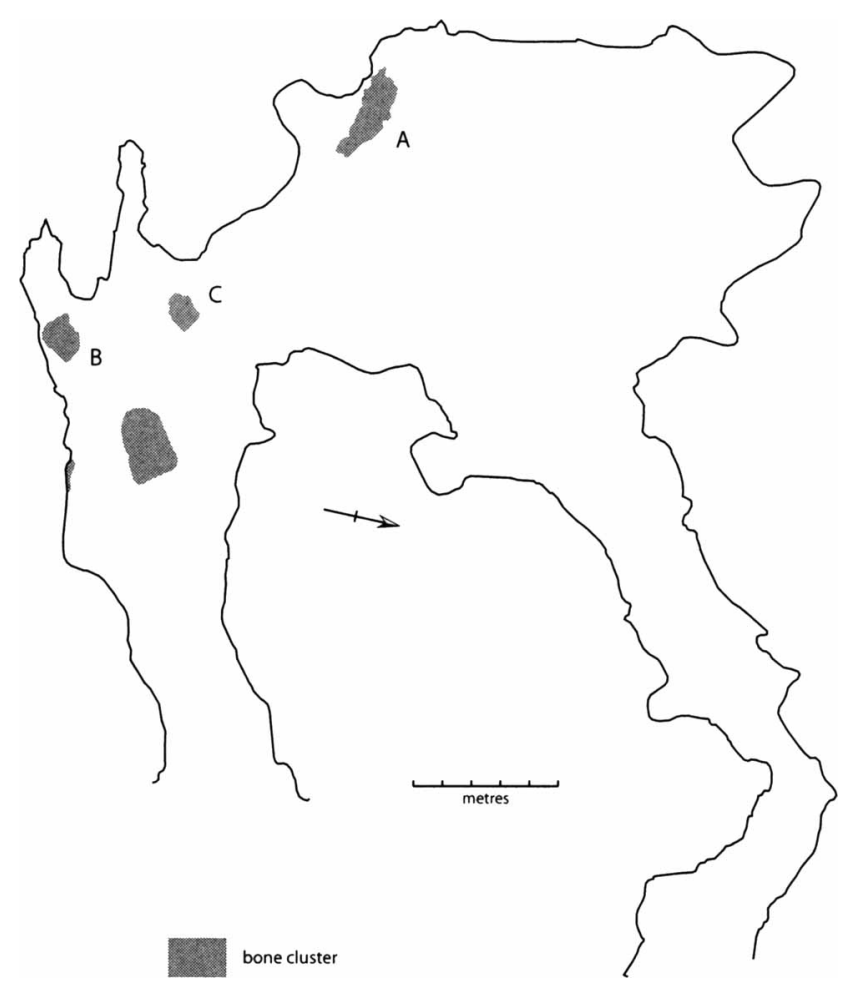

Figure 3 Plan of Ajdovska Jama (Slovenia) showing the locations of the Neolithic burials.

\section{AJDOVSKA JAMA}

Ajdovska Jama (The Pagan's Cave), which is the focus of this paper, is situated in southeast Slovenia near the city of Krško $\left(45^{\circ} 58^{\prime} \mathrm{N}, 15^{\circ} 29^{\prime} \mathrm{E}\right)$. Occupying an east-facing position in limestone hills $5 \mathrm{~km}$ from the River Sava, the cave has 2 entrances at 240 and $244 \mathrm{~m}$ asl, respectively, which lead along passages to a central chamber $\sim 17 \mathrm{~m}$ in diameter (Figure 3). Archaeological investigations, conducted on various occasions since 1884 , have demonstrated periodic human use of the cave from the Paleolithic to the Middle Ages.

The site is well known for its burial remains, the majority of which were recovered in excavations by Milena Horvat between 1982 and 1987 (Horvat 1989). The human bones occurred in a horizon $\sim 10 \mathrm{~cm}$ thick, which was divided into 2 stratigraphic units (43 and 44), on the basis of their colors and the differing amounts of charcoal present. Five distinct clusters of bones were identified, 4 in the south passage and 1 toward the rear of the main chamber (Figure 3). Bone preservation was generally poor and the crania were missing. Therefore, aging and sexing of the burials were based on surviving long bones and mandibles (Corrain and Capitanio 1991). The entire assemblage comprises a minimum of 31 individuals -15 adults ( 7 males and 8 females) and 16 children. On the basis of associated pottery and other archaeological finds, the burials were assigned to the Late Neolithic Alpine Lengyel culture, and this is broadly confirmed by radiometric ${ }^{14} \mathrm{C}$ ages on charred plant material from the same archaeological horizon, which range from $5620 \pm 130$ (Z-1044) to $5120 \pm$ $130 \mathrm{BP}(\mathrm{Z}-1042)$, with outliers of $4700 \pm 200 \mathrm{BP}(\mathrm{Z}-1179)$ and $2900 \pm 120 \mathrm{BP}(\mathrm{Z}-1603)$ (Srdoč et al. 1984, 1987, 1989, 1992; Obelić et al. 1994). 
The cave has been interpreted as a "necropolis" used by a farming community that practiced excarnation. It has been suggested that the dead were first left exposed on the cave floor (possibly in the north passage) and once the skeletons were defleshed, some of the bones were collected up and deposited in the various locations shown in Figure 3. In some cases, stones were placed around the bone clusters, defining the burial area. Personal items were placed next to the bodies, including items of jewelry with the women and weapons with the men. Food items were also placed next to the bodies. These were represented by bones of cattle, sheep, and deer, and pots containing carbonized remains of cereals and pulses (Horvat 1989).

The human remains from Ajdovska Jama were the subject of a previous paleodietary study by Ogrinc (1999; Ogrinc and Budja 2005) in which the carbon and nitrogen isotopes of the bone collagen were analyzed, although no direct ${ }^{14} \mathrm{C}$ dating of the bones was undertaken. Ogrinc analyzed bones from both stratigraphic units in 3 of the clusters (Figure $3 \mathrm{~A}-\mathrm{C}$ ). She assumed that the 2 stratigraphic units related to distinct periods: the lower unit (44) she dated to $6000 \mathrm{BP}$ (revised to $6400 \mathrm{BP}$ by Ogrinc and Budja [2005]) and the upper unit (43) to 5300 BP. In total, Ogrinc undertook stable isotope analysis of bones from 25 individuals (adults and children) (Figure 4a); she also analyzed animal bones and plant remains to obtain comparative information on the local food web.
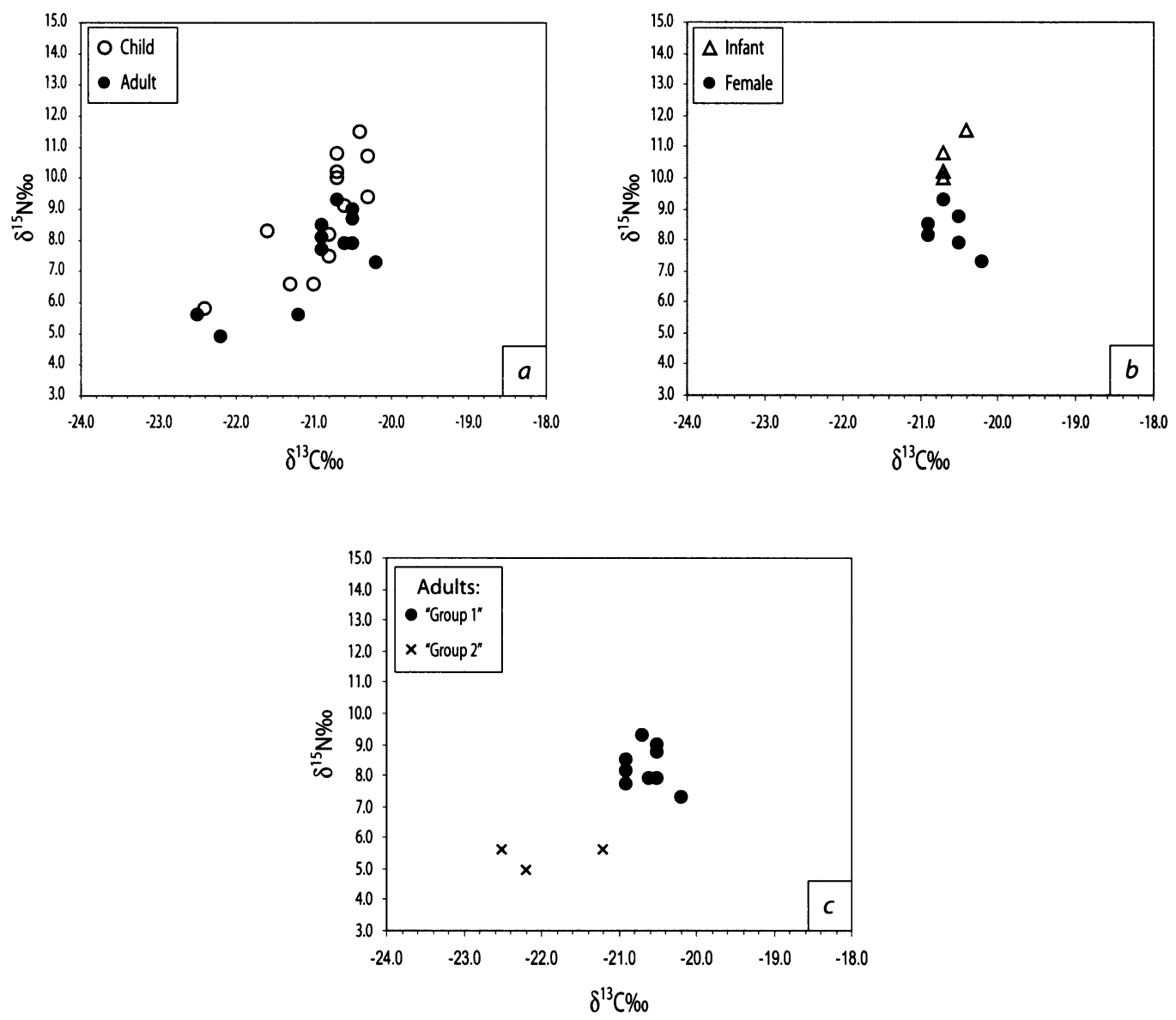

Figure 4 Carbon and nitrogen stable isotope ratios for human bone collagen from Ajdovska Jama obtained by Ogrinc (1999): a) all samples analyzed (adults + children); b) infants (0-2 yr) and adult females; c) adults, apparently showing 2 groups with differing $\delta^{15} \mathrm{~N}$ signatures. 
Ogrinc (1999) interpreted the stable isotope results for the human bones as indicative of a population with a relatively homogeneous diet that consisted mainly of meat from domestic and wild herbivores, but in which individual food preferences could be observed. She was also able to show a "nursing effect" where the bone collagen $\delta^{15} \mathrm{~N}$ values of infants $(0-2 \mathrm{yr})$ were on average $2 \%$ o heavier than the adult females (Figure $4 b$ ), whereas older children did not consistently show this effect. Ogrinc and Budja (2005) applied the concentration-weighted linear mixing model (IsoConc) proposed by Phillips and Koch (2002) and re-interpreted the stable isotope data as representing a diet based mainly on meat from domestic and wild herbivores (average of $44 \%$ ) and cereals (average of $39 \%)$.

The present study undertook paired AMS ${ }^{14} \mathrm{C}$ and stable $\mathrm{C}$ and $\mathrm{N}$ isotope analyses of bone collagen from 15 individuals that had previously been analyzed by Ogrinc. These bones came from the 3 richest clusters (A, B, and C) and both stratigraphic units (43 and 44). The objectives were to: i) obtain direct ${ }^{14} \mathrm{C}$ age measurements on the human bones and compare the results with the radiometric ages previously obtained on associated materials; ii) investigate any age and stable isotope differences between the different bone clusters and stratigraphic units and compare the stable isotope data with Ogrinc's previous study; and iii) assess the contributions of freshwater resources and $\mathrm{C}_{4}$ plants to the human diet.

\section{MATERIALS AND METHODS}

The bone fragments were decalcified and gelatinized using standard techniques, and transferred to an ultrafilter (Vivaspin ${ }^{\mathrm{TM}} 15,30 \mathrm{kD}$ MWCO) and centrifuged. The ultrafilter retains the $>30-\mathrm{kD}$ molecular weight fraction, which will include un-degraded collagen. The $<30-\mathrm{kD}$ fraction, which contains low molecular weight components such as salts, degraded collagen fragments, and sometimes soil-derived contaminants, was discarded. The $>30-\mathrm{kD}$ fraction was recovered and freezedried in preparation for analysis. The analysis system comprised a Europa Scientific ANCA-MS system consisting of a 20-20 isotope ratio mass spectrometer interfaced to a Roboprep CHN sample converter unit, operating in continuous-flow mode. This enables the measurement of $\delta^{15} \mathrm{~N}$ and $\delta^{13} \mathrm{C}$, nitrogen and carbon content, and $\mathrm{C} / \mathrm{N}$ ratios. Graphite was prepared from the $\mathrm{CO}_{2}$ prior to $\mathrm{AMS}{ }^{14} \mathrm{C}$ measurement using published techniques (Bronk Ramsey and Hedges 1997; Bronk Ramsey et al. 2000).

The ultrafiltrated gelatin usually produces collagen of an improved quality, as shown by the $\mathrm{C} / \mathrm{N}$ ratios (Bronk Ramsey et al. 2004). Collagen quality and chemical integrity were assessed using the atomic ratio of carbon to nitrogen ( $\mathrm{C} / \mathrm{N}$ atomic ratio), the percentage of collagen extracted compared with the starting weight of bone (wt\% collagen) and the carbon yield of the collagen on combustion. Problem bones may be screened on the basis of these parameters. Bone is considered acceptable if measured $\mathrm{C} / \mathrm{N}$ ratios of collagen fall between 2.9 and 3.5. In addition, bone that is composed of less than $1 \mathrm{wt} \%$ collagen is not dated.

\section{RESULTS AND DISCUSSION}

The AMS ${ }^{14} \mathrm{C}$ and stable isotope results from the present study are presented in Table 1 along with the corresponding stable isotope data obtained by Ogrinc (1999). Of the 15 samples analyzed, only 10 produced collagen suitable for analysis. The ${ }^{14} \mathrm{C}$ results all fall within a tightly constrained age range of $5485 \pm 50$ to $5340 \pm 36 \mathrm{BP}$, confirming the archaeological dating to the Late Neolithic. There is no evidence of a population dating to $6400 \mathrm{BP}$ as proposed by Ogrinc and Budja (2005). 


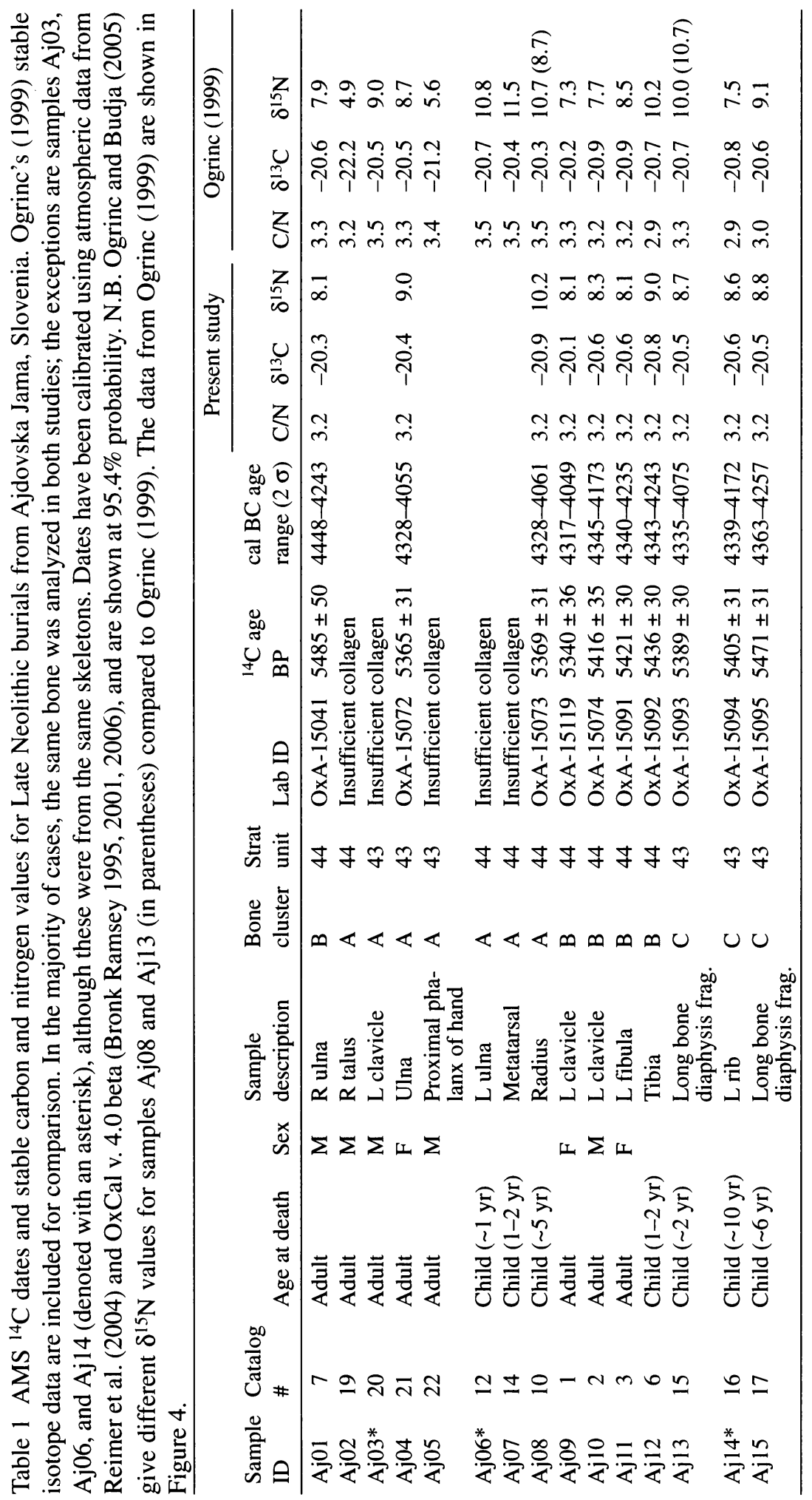




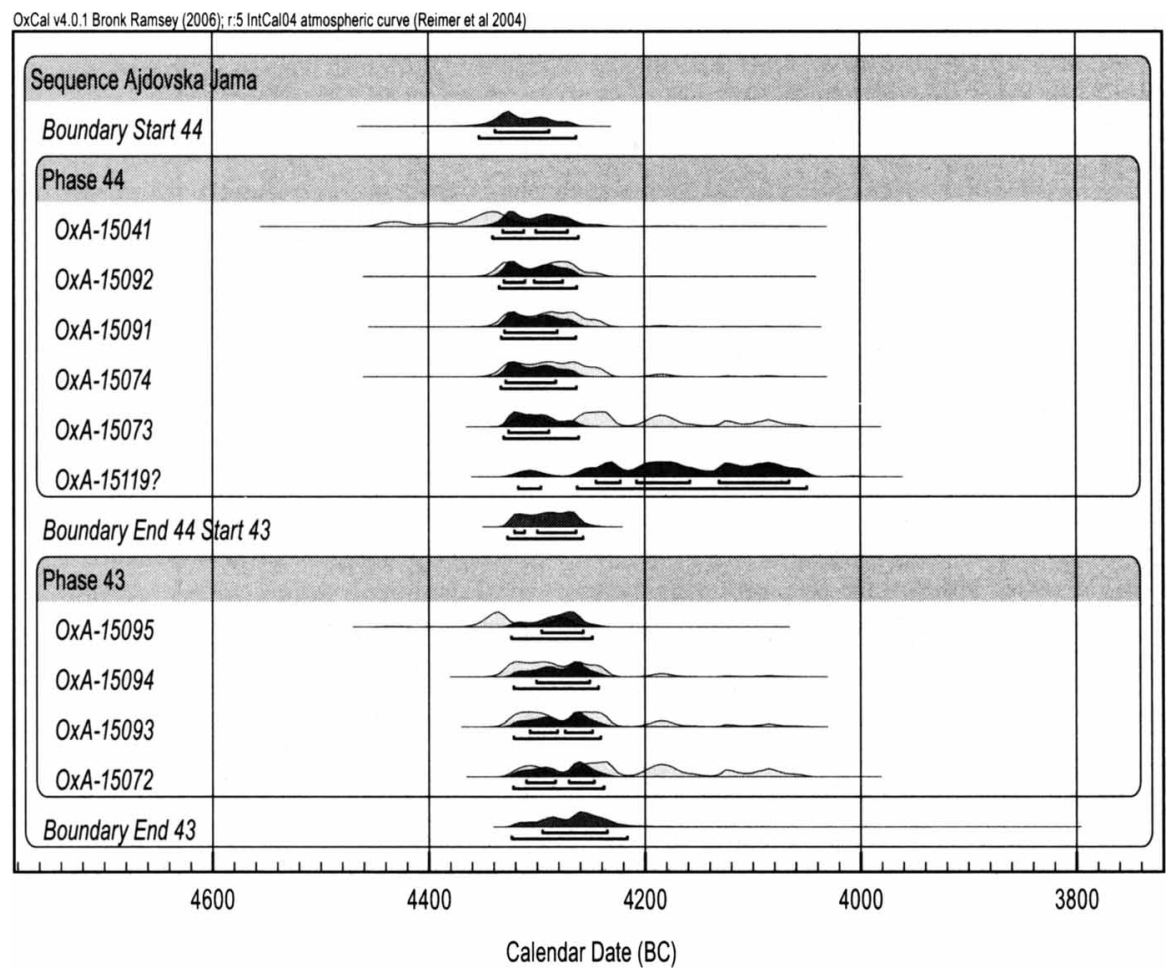

Figure 5 Probability distributions of Bayesian modeled age ranges of human bone samples dated from Ajdovska Cave. Plot generated using OxCal v 4.0 (Bronk Ramsey 1995, 2001, 2006). The overall agreement index for this model was $82.9 \% .{ }^{14} \mathrm{C}$ likelihoods are shown with lighter shading, while posterior probability distributions are shown in bold shades. See Table 2 for actual posterior range data.

The AMS dates have been calibrated against the IntCal04 data set (Reimer et al. 2004) using OxCal v 4.0 (Bronk Ramsey 1995, 2001, 2006). There is a dearth of prior archaeological information associated with the selected skeletons from the site, particularly in terms of any relative sequencing, since the total thickness of the bone-bearing horizon is only about $10 \mathrm{~cm}$. The dated samples were modeled as 2 phases (44 and 43), in accordance with Horvat's original stratigraphic interpretation. The results of this Bayesian analysis are shown in Figure 5 and Table 2. The overall agreement index for the model was $82.9 \%$. Subsequent runs of the model showed consistent agreement indices. One of the posterior distributions yielded low agreement indices, suggesting strongly that it did not fit the inferred phasing (OxA-15119), and this was therefore questioned (Table 2). The modeling indicates that burial deposition began after 4340-4290 BC (68.2\% probability) and that the burials represent a brief period of activity; total span is equivalent to $5-120 \mathrm{yr}$ (95.4\% probability) with the highest probability associated with 10-20 yr (Figure 6). The terrestrial stable isotope signals (see below) suggest a lack of a reservoir effect, and this strengthens the confidence in the reliability of these human bone determinations.

The underlying principle of dietary tracing using stable isotopes is that the ratios of carbon and nitrogen isotopes in bone collagen reflect those in the average diet-more specifically, the protein portion of the diet. With each step along the food chain, there is fractionation of 1 isotope relative to another, resulting in a change in ratio ("trophic enrichment"). Most workers assume a slight enrichment in $\delta^{13} \mathrm{C}$ (up to $1 \%$ ) and an average enrichment in $\delta^{15} \mathrm{~N}$ of $3 \%$ o between food source and consumer. 
Table 2 Posterior distributions for the Ajdovska Jama Bayesian model. Ranges for start and end boundaries as well as overall span are shown in cal yr BC, as well as for each posterior distribution. The results have been rounded to the nearest 5 yr. These data are shown in Figure 5.

Posterior distributions (cal age range $\mathrm{BC}$ )

\begin{tabular}{lrrrrrr} 
& \multicolumn{2}{c}{$68.2 \%$} & & \multicolumn{2}{c}{$95.4 \%$} & \\
\cline { 2 - 3 } & from & to & & from & to & Agreement index \\
\hline Phase 44 & 4340 & 4290 & & 4355 & 4265 & \\
Boundary Start 44 & 4330 & 4270 & & 4340 & 4260 & 88.5 \\
OxA-15041 & 4330 & 4280 & & 4335 & 4265 & 103.9 \\
OxA-15092 & 4330 & 4280 & & 4335 & 4265 & 111.1 \\
OxA-15091 & 4329 & 4285 & & 4335 & 4265 & 116 \\
OxA-15074 & 4330 & 4290 & & 4330 & 4260 & 88.2 \\
OxA-15073 & 4245 & 4070 & & 4320 & 4050 & questioned \\
OxA-15119 & 4320 & 4265 & & 4330 & 4260 & \\
Boundary End 44/Start 43 & & & & & \\
Phase 43 & 4300 & 4260 & & 4325 & 4250 & 53.3 \\
OxA-15095 & 4300 & 4250 & 4320 & 4245 & 112.1 \\
OxA-15094 & 4310 & 4250 & & 4320 & 4240 & 113.4 \\
OxA-15093 & 4310 & 4250 & 4325 & 4240 & 98.5 \\
OxA-15072 & 4295 & 4235 & 4325 & 4220 & \\
Boundary End 43 & 5 & 60 & 5 & 120 & \\
Span & & & & & \\
\hline
\end{tabular}

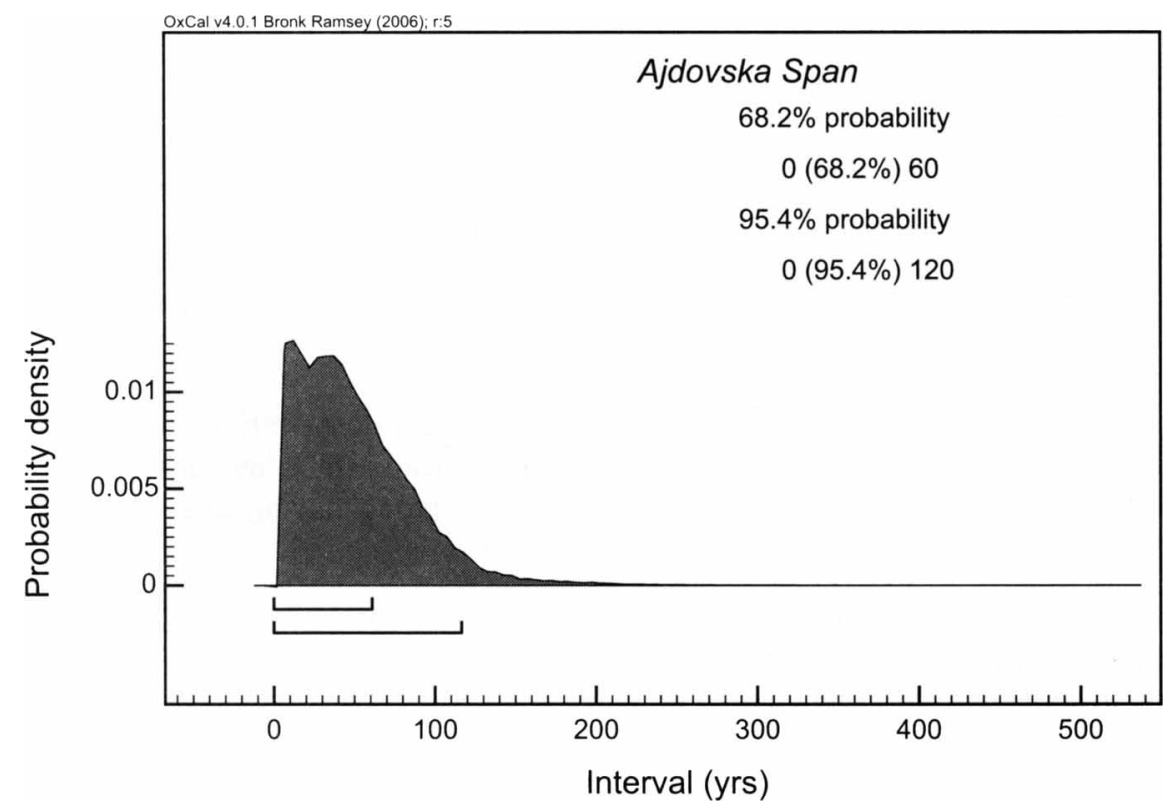

Figure 6 Bayesian span for the modeled data presented in Figure 5. The distribution represents the span of both archaeological phases and suggests that the highest probability is associated with a very brief period. 
In the studies of Ogrinc (1999) and Ogrinc and Budja (2005), the $\delta^{15} \mathrm{~N}$ values for the bone collagen of the adults ranged from +4.9 to $+9.3 \%$, which is unusually large for a single population (Figure 4c). These data were interpreted as indicating a dietary regime with wide variation in individual food preferences.

The $\delta^{15} \mathrm{~N}$ values for adults obtained during the present study show a much narrower range of $<1 \%$, from +8.1 to $+9.0 \%$ (Figure 7). None of the adult samples for which Ogrinc obtained low $(<6 \%$ ) $\delta^{15} \mathrm{~N}$ values produced a quality of collagen suitable for analysis, based on the parameters discussed above. It could be argued that this is why the range in our study is smaller and there are no low $\delta^{15} \mathrm{~N}$ values. However, it may be that the low $\delta^{15} \mathrm{~N}$ samples analyzed by Ogrinc contained non-collagenous contaminants, which have influenced her results. There has been little direct comparison of stable isotope bone collagen values obtained with and without the ultrafiltration step, and so at present we have no empirical data to support this argument. However, an effect has been demonstrated on ${ }^{14} \mathrm{C}$ ages (Bronk Ramsey et al. 2004; Higham et al. 2006), which implies that in some circumstances (e.g. low collagen content) stable isotope values could also be influenced.

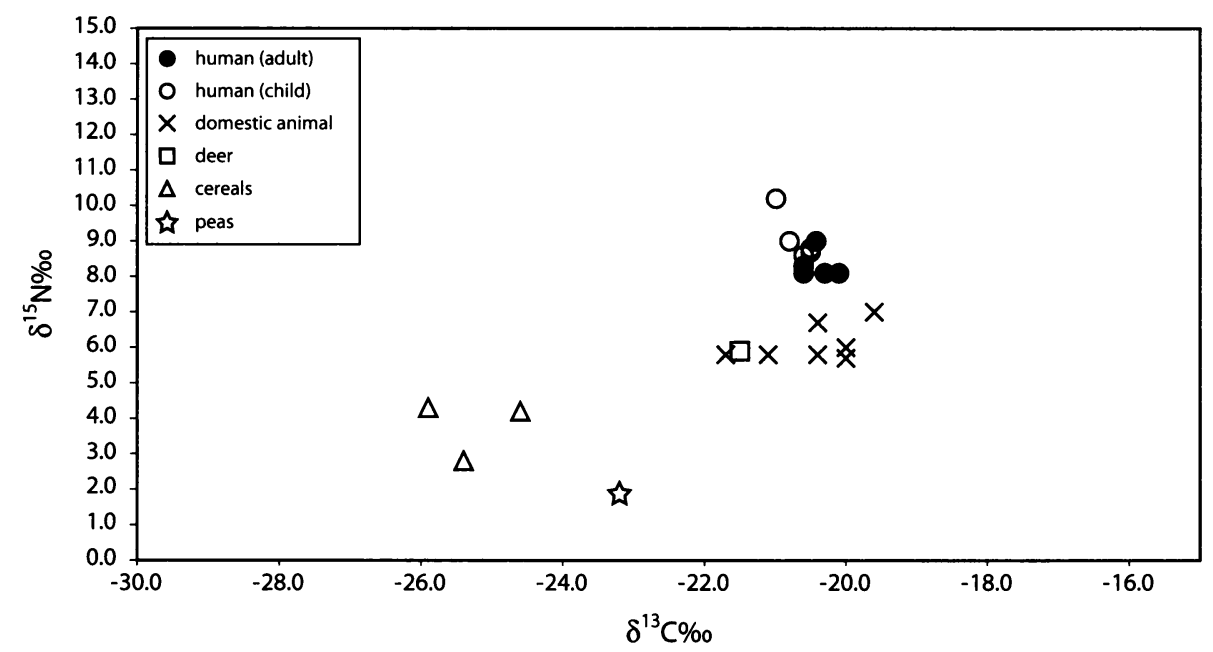

Figure 7 Collagen carbon and nitrogen stable isotope ratios for human adults and children from Ajdovska Jama obtained in the present study, plotted against Ogrinc's (1999) food source data.

Of the 4 children for which results were obtained in the present study, only 1 shows a significantly higher $\delta^{15} \mathrm{~N}$ value compared to the adults, which may be indicative of a "nursing effect" (Figure 7). Interestingly, this is not one of the youngest children in the group, having an age at death of $\sim 5 \mathrm{yr}$ (Table 1, sample Aj08).

From a comparison of her human and food source stable isotope data, Ogrinc (1999) concluded that the human diet consisted predominantly of meat from domestic and wild herbivores, with very little of the protein being derived from plant sources. The re-interpretation (Ogrinc and Budja 2005) proposed a diet based mainly on meat from domestic and wild herbivores (average of 44\%) and cereals (average of 39\%).

The present study favors a somewhat different interpretation. In Figure 7, our human collagen stable isotope results are compared with Ogrinc's data for animal and plant food sources. The difference in average $\delta^{15} \mathrm{~N}$ between the human adults and herbivores is $2.3 \%$. This enrichment would be consis- 
tent with a largely meat-based diet if one assumes a 3\%o trophic shift. However, judging from ethnohistorical evidence, such a diet would be highly unusual for a peasant farming society in southeastern Europe where cultivated plants (cereals, legumes, and fruits) typically provide the bulk of the diet, with a modest contribution from dairy products, and meat is regarded as a luxury.

Since animal products generally contain more protein per unit weight than do most plant foods, particularly in a cooked state, which is how they would normally be consumed by humans (Table 3), the meat portion of the diet may be disproportionately represented in bone collagen (Bonsall et al. 1997). Moreover, while most isotopic studies of human diet employ a trophic enrichment of $3 \%$ o for $\delta^{15} \mathrm{~N}$, recent research suggests that the enrichment in humans can often be significantly greater than this. For example, our work in the Iron Gates indicates an enrichment of 5.4-6.7\%o in Mesolithic humans over the riverine fish on which their diet was based (Bonsall, unpublished data), while average collagen $\delta^{15} \mathrm{~N}$ values for Middle and Early Upper Paleolithic populations in western Europe are typically $5 \%$ o higher than those of their main prey animals such as reindeer, bovids, and horse (estimate based on data presented by Drucker and Bocherens 2004).

Table 3 Nutritional value of selected (modern) animal and plant foods (data from Paul and Southgate 1978). In cooked form, the protein content of meat on average is approximately 4 times greater than that of cereals and pulses.

\begin{tabular}{lcccc}
\hline Food & $\mathrm{CH}(\mathrm{g})$ & Fat $(\mathrm{g})$ & Protein $(\mathrm{g})$ & $\mathrm{Kcal} / 100 \mathrm{~g}$ \\
\hline Beef (sirloin, raw) & 0 & 22.8 & 16.6 & 272 \\
Beef (sirloin, roast) & 0 & 21.1 & 23.6 & 284 \\
Beef (rump, grilled) & 0 & 12.1 & 27.3 & 218 \\
Lamb (leg, raw) & 0 & 18.7 & 17.9 & 240 \\
Lamb (leg, roast) & 0 & 17.9 & 26.1 & 266 \\
Pork (leg, raw) & 0 & 22.5 & 16.6 & 269 \\
Pork (leg, roast) & 0 & 19.8 & 26.9 & 286 \\
Venison (roast) & 0 & 6.4 & 35.0 & 198 \\
Cheese (Camembert type) & Trace & 23.2 & 22.8 & 300 \\
Milk (cow's) & 4.7 & 3.8 & 3.3 & 65 \\
Wheat (wholemeal flour) & 65.8 & 2.0 & 13.2 & 318 \\
Barley (raw) & 83.6 & 1.7 & 7.9 & 360 \\
Barley (boiled) & 27.6 & 0.6 & 2.7 & 120 \\
Beans (haricot, raw) & 45.5 & 1.6 & 21.4 & 271 \\
Beans (haricot, boiled) & 16.6 & 0.5 & 6.6 & 93 \\
Beans (broad, boiled) & 7.1 & 0.6 & 4.1 & 48 \\
Peas (raw) & 10.6 & 0.4 & 5.8 & 67 \\
Peas (boiled) & 7.7 & 0.4 & 5.0 & 52 \\
Lentils (raw) & 53.2 & 1.0 & 23.8 & 304 \\
Lentils (boiled) & 17.0 & 0.5 & 7.6 & 99 \\
\hline
\end{tabular}

Therefore, we would suggest that the average $\delta^{15} \mathrm{~N}$ value of $+8.3 \%$ for the adult humans from Ajdovska Jama does not necessarily indicate heavy reliance on the meat of herbivores as suggested by Ogrinc (1999) and Ogrinc and Budja (2005), but is entirely consistent with a mixed diet of plant and animal products. Furthermore, the tight clustering of the adult $\delta^{13} \mathrm{C}$ and $\delta^{15} \mathrm{~N}$ values in the present study does not support Ogrinc's (1999) suggestion of significant variation in individual food preferences among the Late Neolithic population. 
It is instructive to compare our data with those for modern people who are vegans and vegetarians. In a study by Macko et al. (1999), hair samples from 2 vegans gave $\delta^{15} \mathrm{~N}$ values of $+7.2 \%$, while hair samples from 8 ovo-lacto-vegetarians (who consumed a combination of plants, eggs, and milk products) yielded $\delta^{15} \mathrm{~N}$ values in the range +8.5 to $+10.9 \%$.

The suggestion that plant foods contributed significantly to the diet of the Ajdovska Jama population also receives support from dental evidence. Table 3 shows that cereals and pulses are rich sources of carbohydrates when compared to meat from terrestrial herbivores. Heavier reliance on carbohydrates may be reflected in a greater prevalence of dental caries ("tooth decay": Larsen 1997). Although adult dental remains at Ajdovska Cave were under-represented and the caries rate cannot be calculated reliably, the presence of 2 out of 4 mandibles exhibiting carious lesions and/or ante mortem tooth loss and 3 decayed loose teeth out of a total of 19 implies that it would have been high. This contrasts with the situation among Mesolithic populations in the Iron Gates, where the diet was high in animal (mainly fish) protein and low in carbohydrate and caries rates were correspondingly very low (Bonsall et al. 1997).

The average $\delta^{13} \mathrm{C}$ value for the adults analyzed in the present study is $-20.5 \%$, which suggests a diet based on $\mathrm{C}_{3}$ food sources. There is no evidence for significant consumption of $\mathrm{C}_{4}$ crop plants or meat from animals fed regularly on $\mathrm{C}_{4}$ plants, and this is highlighted by a comparison of the $\delta^{13} \mathrm{C}$ values for the Late Neolithic skeletons from Ajdovska Jama with the much heavier values found in early Iron Age burials from Magdalenska Gora also in the Sava catchment, $60 \mathrm{~km}$ to the west of Ajdovska Jama, which according to Murray and Schoeninger (1988) reflect high levels of millet consumption (Figure 8).

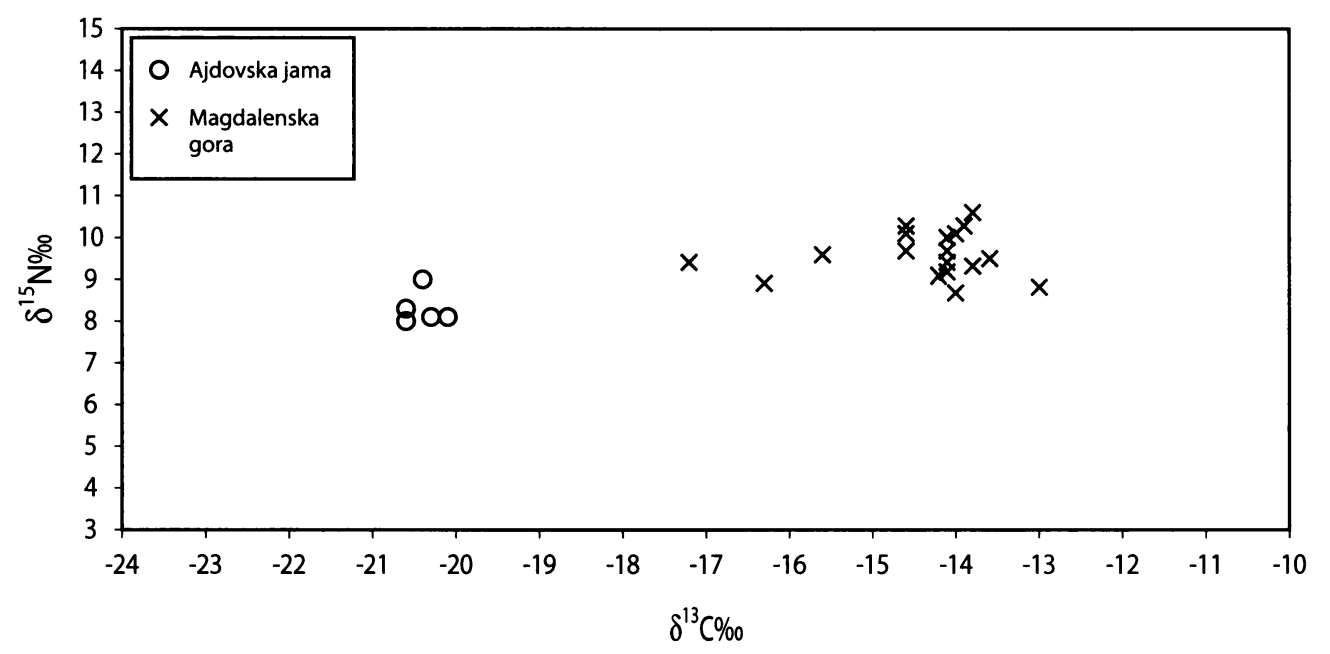

Figure 8 Collagen carbon and nitrogen stable isotope ratios for human adults from Ajdovska Jama (Late Neolithic) and Magdalenska Gora (early Iron Age). Both sites are in the Sava river catchment, $\sim 60 \mathrm{~km}$ apart (Magdalenska Gora data from Murray and Schoeninger 1988).

Similarly, $\delta^{13} \mathrm{C}$ values of $-20.1 \%$ o to $-20.9 \%$ coupled with the relatively low $\delta^{15} \mathrm{~N}$ values argue against a significant contribution of fish to the diet, and no fish bones were present among the faunal remains from Late Neolithic contexts at Ajdovska Jama. 


\section{CONCLUSIONS}

The AMS ${ }^{14} \mathrm{C}$ ages on human bone collagen presented in this paper confirm the archaeological dating of the burials in Ajdovska Jama, Slovenia, to the Late Neolithic, 5400 BP (4300 cal BC), with no evidence of burial activity around $6400 \mathrm{BP}$ as suggested by Ogrinc and Budja (2005). Bayesian analysis of the ${ }^{14} \mathrm{C}$ data suggests the people were buried during a period of no more than $120 \mathrm{yr}$ (95.4\% probability). The associated carbon and nitrogen isotope ratios indicate a population with a "terrestrial" diet in which the protein was derived very largely or exclusively from $\mathrm{C}_{3}$ plant and animal food sources. Taken together with the archaeobotanical, physical anthropological, and zooarchaeological evidence from the site, the data are suggestive of a mixed farming economy. Meat from wild herbivores was probably included in the diet, but there is no archaeological or isotopic evidence for the regular consumption of fish, in spite of the relative proximity of the River Sava. Nor is there evidence for the use of $\mathrm{C}_{4}$ plants as human food or animal fodder. The Ajdovska Jama burials thus belong to a period when farming had already been established in the region for over a millennium, but before millet (the only $\mathrm{C}_{4}$ crop plant grown widely in prehistoric Europe) became economically important. From the perspective of stable isotope research, Ajdovska Jama constitutes an important reference sample of an established Neolithic farming community from the Danube Basin.

\section{ACKNOWLEDGMENTS}

Clive Bonsall's work on the human bone material from Ajdovska Jama was undertaken as part of his Northern Adriatic Project, supported by research grants from the British Academy, the Carnegie Trust for the Universities of Scotland, and the Munro Fund, Hayter Fund, and Development Trust Research Fund of the University of Edinburgh. The AMS ${ }^{14} \mathrm{C}$ measurements and stable isotope analyses were funded by an AHRC-NERC ORADS award to CB. The authors wish to thank László Bartosiewicz and an anonymous referee for their comments on a preliminary draft of the paper. We are also grateful to Nives Kokeza and Matija Črešnar for Slovene-English translations, and to Professor Mihael Budja for his invaluable assistance at an early stage of the research.

\section{REFERENCES}

Bartosiewicz L, Bonsall C, Boroneant V, Stallibrass S. 2001. New data on the prehistoric fauna of the Iron Gates: a case study from Schela Cladovei, Romania. In Kertés R, Makkay J, editors. From the Mesolithic to the Neolithic. Budapest: Archaeolingua (Main Series). p 15-21.

Bonsall C, Lennon R, McSweeney K, Stewart C, Harkness D, Boroneanţ V, Payton R, Bartosiewicz L, Chapman JC. 1997. Mesolithic and Early Neolithic in the Iron Gates: a palaeodietary perspective. Journal of European Archaeology 5(1):50-92.

Bonsall C, Cook G, Lennon R, Harkness D, Scott M, Bartosiewicz L, McSweeney K. 2000. Stable isotopes, radiocarbon and the Mesolithic-Neolithic transition in the Iron Gates. Documenta Praehistorica 27:119-32.

Bonsall C, Cook GT, Hedges REM, Higham TFG, Pickard C, Radovanović I. 2004. Radiocarbon and stable isotope evidence of dietary change from the $\mathrm{Me}$ solithic to the Middle Ages in the Iron Gates: new results from Lepenski Vir. Radiocarbon 46(1):293-300.

Bronk Ramsey C. 1995. Radiocarbon calibration and analysis of stratigraphy: the OxCal program. Radiocarbon 37(2):425-30.
Bronk Ramsey C. 2001. Development of the radiocarbon calibration program. Radiocarbon 43(2A):355-63.

Bronk Ramsey C. 2006. OxCal program v 4.0 [software and documentation]. URL: http://c14.arch.ox.ac.uk/ oxcal/hlp_contents. html.

Bronk Ramsey C, Hedges REM. 1997. Hybrid ion sources: radiocarbon measurements from microgram to milligram. Nuclear Instruments and Methods in Physics Research B 123(1-4):539-45.

Bronk Ramsey C, Pettitt PB, Hedges REM, Hodgins GWL, Owen DC. 2000. Radiocarbon dates from the Oxford AMS system: Archaeometry Datelist 30. Archaeometry 42:459-79.

Bronk Ramsey C, Higham TFG, Bowles A, Hedges REM. 2004. Improvements to the pretreatment of bone at Oxford. Radiocarbon 46(1):155-63.

Cook GT, Bonsall C, Hedges REM, McSweeney K, Boroneant V, Pettitt $\mathrm{PB}$. 2001. A freshwater diet-derived ${ }^{14} \mathrm{C}$ reservoir effect at the Stone Age sites in the Iron Gates Gorge. Radiocarbon 43(2A):453-60.

Cook GT, Bonsall C, Hedges REM, McSweeney K, Boroneanţ V, Bartosiewicz L, Pettitt PB. 2002. Problems of dating human bones from the Iron Gates. Antiquity 
76(291):77-85.

Corrain C, Capitanio M. 1991. La necropli di Adjovska jama (Slovenia). Poročilo o raziskovanju paleolita, neolita in eneolita $v$ Sloveniji 29:207-47. In Italian.

Drucker D, Bocherens H. 2004. Carbon and nitrogen stable isotopes as tracers of change in diet breadth during Middle and Upper Palaeolithic Europe. International Journal of Osteoarchaeology 14(3-4):162-77.

Higham T, Bronk Ramsey C, Karavanić I, Smith FH, Trinkaus E. 2006. Revised direct radiocarbon dating of the Vindija $\mathrm{G}_{1}$ Upper Paleolithic Neandertals. Proceedings of the National Academy of Sciences of the USA 103(3):553-7.

Horvat M. 1989. Ajdovska jama pri Nemški vasi. Ljubljana: Znanstveni inštitut Filozofske fakultete. In Slovene.

Larsen CS. 1997. Bioarchaeology: Interpreting Behaviour from the Human Skeleton. Cambridge: Cambridge University Press. $474 \mathrm{p}$.

Macko SA, Lubec G, Teschler-Nicola M, Andrusevich V, Engel MH. 1999. The Ice Man's diet as reflected by the stable nitrogen and carbon isotopic composition of his hair. The FASEB Journal 13:559-62.

Murray M, Schoeninger M. 1988. Diet, status and complex social structure in Iron Age Central Europe: some contributions of bone chemistry. In: Gibson DB, Geselowitz MN, editors. Tribe and Polity in Late Prehistoric Europe: Demography, Production and Exchange in the Evolution of Complex Social Systems. New York: Plenum. p 155-76.

Obelić B, Horvatinčić N, Srdoč D, Krajcar Bronić I, Sliepčević A, Grgić S. 1994. Rudjer Bošković Institute radiocarbon measurements XIII. Radiocarbon 36(2):303-24.

Ogrinc N. 1999. Stable isotope evidence of the diet of the Neolithic population in Slovenia-a case study: Ajdovska jama. Documenta Praehistorica 26:193-200.

Ogrinc N, Budja M. 2005. Paleodietary reconstruction of a Neolithic population in Slovenia: a stable isotope approach. Chemical Geology 218(1-2):103-16.

Paul AA, Southgate DAT. 1978. McCance and Widdowson's the Composition of Foods. 4th edition. London: Her Majesty's Stationery Office.

Phillips DL, Koch PL. 2002. Incorporating concentration dependence in stable isotope mixing models. Oecologia 130(1):114-25.

Reimer PJ, Baillie MGL, Bard E, Bayliss A, Beck JW, Bertrand CJH, Blackwell PG, Buck CE, Burr GS, Cutler KB, Damon PE, Edwards RL, Fairbanks RG, Friedrich M, Guilderson TP, Hogg AG, Hughen KA, Kromer B, McCormac G, Manning S, Bronk Ramsey C, Reimer RW, Remmele S, Southon JR, Stuiver M, Talamo S, Taylor FW, van der Plicht J, Weyhenmeyer CE. 2004. IntCal04 terrestrial radiocarbon age calibration, 0-26 cal kyr BP. Radiocarbon 46(3):1029-58.

Srdoč D, Obelić B, Horvatinčić N, Krajcar I, Sliepčević A. 1984. Rudjer Bošković Institute radiocarbon measurements VIII. Radiocarbon 26(3):449-60.

Srdoč D, Horvatinčić N, Obelić B, Krajcar Bronić I, Sliepčević A. 1987. Rudjer Bošković Institute radiocarbon measurements IX. Radiocarbon 29(1):115-34.

Srdoč D, Obelić B, Horvatinčić N, Krajcar Bronić I, Sliepèević A. 1989. Rudjer Bošković Institute radiocarbon measurements XI. Radiocarbon 31(1):85-98.

Srdoč D, Horvatinčić N, Krajcar Bronić I, Obelić B, Sliepèević A. 1992. Rudjer Bošković Institute radiocarbon measurements XII. Radiocarbon 34(1):15575.

Whittle A, Bartosiewicz L, Borić D, Pettitt P, Richards M. 2002. In the beginning: new radiocarbon dates for the Early Neolithic in northern Serbia and southeast Hungary. Antaeus 25:64-117.

Zohary D, Hopf M. 1994. Domestication of Plants in the Old World: the Origin and Spread of Cultivated Plants in West Asia, Europe, and the Nile Valley. 2nd edition. Oxford: Clarendon Press. 264 p. 